\title{
MR. JUSTICE CARDOZO AND PUBLIC LAW*
}

7 HE fairies that presided over Benjamin N. Cardozo's birth 1 were not wholly benign. But they endowed him with one gift of grace far more significant than his rare talents of mind. $\mathrm{He}$ was given a contagious goodness which brought to life the goodness in others. In no invidious sense was the New York Court of Appeals, especially during his presidency, Cardozo's court. And the compulsions of Cardozo's spirit upon those with whom he labored were revealed even through the austerity which insulates the Supreme Court from public knowledge of its intimate life. It is not surprising that the persuasiveness of his personality subdued his immediate environment by its sheer unconscious radiations. It is astonishing that so cloistered a spirit should have . attained such a hold on popular feeling.

Other judges have had much more influence upon the governing forces of American society than fell to Cardozo's lot. Perhaps a few, but at best a very few, judges had as keen an insight into the peculiar rôle of the judge in the American scheme. Finally, there was one judge of greater originality and deeper penetration into the intellectual presuppositions of the judicial process. For it was not merely the language of playful deference which made Cardozo always speak of Holmes as "the Master." But the history of the Supreme Court affords no analogue to the unanimity of lay as well as professional opinion that Chief Judge Cardozo was the one man adequate to fill the historic place vacated by Holmes; nor is there a parallel to the deep feeling of the country as a whole that the death of Cardozo was not merely the premature termination of a distinguished judicial career, but the end of the living energy of one of the most powerful moral resources of the nation.

Ordinarily observations like these are properly uncongenial to pages concerned with the discussion of juristic problems. But in the case of Cardozo the main path to his views on public law leads from his character. His conception of the Constitution cannot be

* In connection with this article, I am under happy obligation to my learned friend Edward F. Prichard, Jr.

440 HARV.

$45^{8}$ YALE

cor. 88 
severed from his conception of a judge's function in applying it. His views of the judge's function derive from his convictions on philosophic issues which implicate the workings of the judicial mind. Such issues in turn involve a man's notions of his relation to the universe. These are abstractions. They seem far removed, let us say, from No. I8o of the October Term, x936. But the clarIiy with which a specific controversy is seen in the context of the larger intellectual issues beneath the formal surface of litigation, and the courage with which such analysis infuses decision and opinion are the ultimate determinants of American public law.

That the task of constitutional construction is a function not of mechanics but of imponderables is now known even by Macaulay's omniscient schoolboy. There is, however, no authorized catalogue of the imponderables; still less is there an accepted organon for striking the balance among competing and conflicting values. Partly because of the wise common-law tradition of ad hoc adjudication, partly because of the distinctive temperament and experience of judges, an avowed juristic philosophy of which individual decisions are particular expressions seldom emerges from the opinions of a judge. The formulation of such a philosophy before a judge ascends the Supreme Bench is a still rarer phenomenon. Barring only Holmes, no man had so completely revealed the map of his mind before he went on the Court as had Cardozo. If surprise there was in anything that he wrote as a Justice, it was not for want of disclosure by him as to the way he looked at questions that would come before him.

Ulimately, a particular decision in a realm not obviously foreclosed by authority ${ }^{1}$ - the decisive field for the play of a judge's creative powers - is the exercise of a high art, what in the happier phraseology of the Seventeenth Century was called a " mystery." But it is a most subtle and complicated art, at its best the end of

2 ". . . the radiating potencies of a decision may go beyond the actual holding. .. . An opinion may be so framed that there is doubt whether the part of it invoked as an authority is to be ranked as a definitive holding or merely a considered dictum." Hawkes v. Hamill, 288 U. S. 52, 58-59 (1933). See Llewellyn, The Rule of Law in Our Case-Law of Contract (1938) 47 YaLE L. J. I243.

89 COL.

YALE 459

HARV. $44 \mathrm{I}$ 


\section{MR. JUSTICE CARDOZO}

a long ratiocinative process. Scientific discoveries, we are told, come to the prepared mind. So the art of adjudication is most imaginatively exercised by those judges who know that the ultimate determination of values is not within the power of formula or measurement. Therefore they explore to the uttermost the rational foundations of what they affirm and what they reject, in order to avoid confusion between their private universe and the universe. All of Cardozo's extrajudicial writings, but more particularly The Nature of the Judicial Process and The Paradoxes of Legal Science are suffused with intimations of what later came from his pen as a Justice, as well as glosses upon what is so shyly expressed in opinions. But his lectures on The Methods of History, Tradition and Sociology, ${ }^{2}$ The Judge as a Legislator ${ }^{3}$ and Liberty and Government ${ }^{4}$ convey explicit analysis of the nature of the issues which cases frame in deceptively logical form. They also reveal the extent of the freedom which judges have in dealing with these issues, as well as the limits of that freedom.

Whereas Holmes all his life was much more occupied with his first love, philosophy, than was Cardozo, he never formulated his philosophy as systematically as did Cardozo except in a short essay or two.5 Indeed, while Holmes was a conscientious student of all the great systems of philosophy and reread such disparate thinkers as Spinoza and John Dewey again and again, he distrusted system, and inclined to the view that systems are apt to be merely the elegant elaborations of a few profound insights. On the other hand, Holmes often made his opinions the vehicles of his philosophic beliefs. He summarized his own views as to ultimates in the amber of his apothegms. While he was alert to the dangers of what the shrewd Lincoln called "pernicious abstractions," particularly in the business of judging, the flair of his mind was for abstractions. Thus it is that from his opinions may be culled sentences which convey his vision of the Constitution in

2 The Nature of the Judictad. Process (1921) Lecture II.

3 Id., Lecture III.

4 Chapters 3 and 4 in The Paradoxes of Legal Science (1928).

s See The Path of the Law and Law in Science and Science in Law in Hormes, Collected Legat Papers (igzo).

442 HARV.

460 YALE

COL. 90 
its relation to the organic process of human society and his conception of the judge as a custodian of that vision.

With Cardozo it was otherwise. Perhaps because he had spelled out his philosophic beliefs and directions in his trilogy, his opinions stuck close to the circumstance of the particular record and indulged sparingly in detachable epigrammatic utterance. But the specific inevitably implicates the general, and in a few instances Cardozo expressed the underlying principles that guided his constitutional function in language and accent not confined to the immediacies of the case.

Indeed the only scope for originality in elucidating the process of constitutional adjudication is the power of putting old truths with freshness. In the abstract, the appropriate ways of looking at the Constitution, when brought within the focus of the judiciary, have been stated in essentially similar terms since Marshall first intoned them in the solemn rhetoric of his day. The sanctions of statesmanship which vindicate this viewpoint were stated with the finality of exquisite scholarship by James Bradley Thayer nearly fifty years ago. ${ }^{7}$ Nor have the intermittent deviations in the applications of Marshall's canons and Thayer's philosophy ever explicitly challenged either canons or philosophy. That the Constitution contains within itself the formulated past but was also designed for the unfolding future; that it is a source of governmental energy no less than of governmental restriction; that in the most difficult areas of adjudication the issues which come before the Court do not primarily present questions as to the meaning of words but invite judgment upon ultimate issues of society which in the now classic language of Mr. Justice Holmes " must be considered in the light of our whole experience and not merely in that of what was said a hundred years ago $" 8$ - these are generalities to which fealty is never denied.

6 The Nature of the Judictal Process (Ig2I); Tre Growtr of the LaW (1924); The Paradoxes of Legal ScIexce (1928).

7 The Origin and Scope of the American Doctrine of Constitulional Laio (1S93) 7 Harv. L. Rev. 129, reprinted in Thayer, Legal Essays (IgOS) I; see Franlifurler and Fisher, The Business of the Suprente Court at the October Terms, 1935 and 1936 (1938) 5I HARv. L. REv. 577, 620-37.

8 Missouri v. Holland, $25^{2}$ U. S. 496,433 (I920).

9 I COL.

YALE $46 \mathrm{I}$

HARV. 443 
But the recognition of their relevance to a specific controversy and the fidelity with which they are applied are the turning points of decisions. Difference among judges is not in knowledge of constitutional precepts but in the persistence and insight with which they respect them. Normally, the raw materials of public law controversies are contemporary affairs, and understanding of their significance is seldom achieved on the bench without considerable prior immersion in affairs. Cardozo is a striking exception. The market place was not his milieu. Sociological problems were not the preoccupation of his leisure moments, his spontaneous writings, or his talk. Iike Holmes, he was sensitive to social tensions and the conflicts of interest not by the bent of his mind, but because the scholar in him made him realize that to be a good judge he had to become conversant with the processes of government and of industry.

Cardozo realized the essentially empiric character of government and the range of discretion implied by its activities. "Time with its tides," he was aware, "brings new conditions which must be cared for by new laws." The need for legislation, its scope and limits, " in last analysis is one of legislative policy, with a wide mar" gin of discretion conceded to the lawmakers. Only in cases of plain abuse will there be revision by the courts." " But review of another's right to exercise policy without substituting one's own presents the most treacherous judicial difficulties. For it necessitates extraordinary powers of detachment not to confound personal disapproval with an enduring constitutional prohibition, not to translate doubts as to wisdom into judgments of law. It implies the rarest gifts of tolerance and a respect for much that is not fully understood. Cardozo recognized that new policies must be perfected or discarded by the test of experience, and must not be judged as though the legislature were a modern Minerva. Except

9 Williams v. Mayor, 289 U. S. 36,46 (1933). See also the observations made more than 100 years ago by William Johnson, one of the ablest members of the Court: "The science of government is the most abstruse of all sciences; if, indecd, that can be called a science which has but few fixed principles, and practically consists in little more than the exercise of a sound discretion, applied to the exigencies of the state as they arise. It is the science of experiment." Anderson v. Dunn, 6 Wheat. 204, 226 (U. S. 1822). 
in the limited instances where explicit constitutional restrictions fence in legislative freedom, laws justify themselves before courts if they manifest

"a pursuit of legitimate ends by methods honestly conceived and rationally chosen. More will not be asked by those who have learned from experience and history that government is at best a makeshift, that the attainment of one good may involve the sacrifice of others, and that compromise will be inevitable until the coming of Utopia." 10

Taxation is the most sensitive area of contemporary government, but the intellectual perspective in which Cardozo placed tax measures induced by social rather than fiscal motives was expressive of his general attitude toward the diverse manifestations of the modern state:

"Systems of taxation are not framed, nor is it possible to frame them, with perfect distribution of benefit and burden. Their authors must be satisfied with a rough and ready form of justice. This is true in special measure while the workings of a novel method are untested by a rich experience. There must be advance by trial and error. . . I In discarding as arbitrary symbols the lines that it [the legislature] has chosen, there is danger of forgetting that in social and economic life the grooves of thought and action are not always those of logic, and that symbols may mean as much as conduct has put into them." 11

Since language is the sword by which the judiciary intervenes in the legislative process, those who wield it must be unremittingly on guard against its hazards:

"A fertile source of perversion in constitutional theory is the tyranny of labels. Out of the vague precepts of the Fourteenth Amendment a court frames a rule which is general in form, though it has been wrought under the pressure of particular situations. Forthwith another situation is placed under the rule because it is fitted to the words, though related faintly, if at all, to the reasons that brought the rule into existence." 12

10 Stewart Dry Goods Co. v. Lewis, 294 U. S. 550, 577 (1935) (dissenting).

11 Liggett Co. v. Lee, 288 U. S. 5I7, 586 (1933) (dissenting).

12 Snyder v. Massachusetts, 29I U. S. 97 , II4 (1934).

93 cor. 


\section{II}

The main stuff of contemporary Supreme Court litigation is fairly indicated by the fact that both the first and the last opinions written by Mr. Justice Cardozo arose out of the interaction of government and business. Nor does it urge significance unduly to note that in his first opinion ${ }^{13}$ Cardozo spoke only for himself, Mr. Justice Brandeis and Mr. Justice Stone, while his last opinion, ${ }^{14}$ announced in his absence by the Chief Justice, was on behalf of a majority of the Court. The economic and social context of Cardozo's period of service, the spate of legislation which came from Congress and the states, and the resistances to which it gave rise, are too familiar to call even for summary.

Since Chisholm v. Georgia, ${ }^{15}$ Supreme Court decisions have on occasion furnished materials for popular discussion. But never in our history was interest in the Court so continuous nor were its opinions so extensively canvassed in the lay press as during the incumbency of Cardozo. To a very considerable degree, therefore, his opinions have become common property. This is not the place for their detailed review. A conspectus of his attitude toward the subjection of economic legislation to judicial review must suffice.

The radiations of taxation have steadily extended the intrusion of government into economic affairs. The tasks of statesmanship in tapping new sources of revenue without killing the goose that lays the golden eggs have correspondingly multiplied. The enormous diversity in types of business activity, the nice calculations involved in making classifications at once fair and effective, the repercussions of different taxes upon diverse enterprises are among the most exigent but elusive riddles for those charged with governing. Clichés like " scientific taxation" cover up a thousand perplexities not susceptible of solution by procedures and criteria familiar to the natural sciences. It is in this perspective of pervasive fiscal needs and the intractable problems they present to

\footnotetext{
13 Coombes v. Getz, 285 U. S. 434,448 (I932) (dissenting).

14 Smyth v. United States, 302 U. S. 329 (1937).

152 Dallas 4 I9 (U.S. I793).
} 
legislators, that tax measures must be seen when brought under the scrutiny of such large phrases as "due process" and "the equal protection of the laws ":

"A tax upon the receipts of a business is not invalid as of course because some forms of business are hit and others are exempt. To bring about that result the assailant of the tax must be able to satisfy the court that the classification had its origin in nothing better than whim and fantasy. . . . This is the heavy burden that the appellant must sustain. Is it a whimsical and fantastic act to tax foreign fire insurance companies upon all their net receipts, including those derived from casualty premiums, when no such tax is imposed upon the receipts of insurance companies that do a casualty business only? If so, the arbitrary quality of the division must have its origin in the fact that the activities of the one class overlap to some extent the activities of the other. But plainly there is no rule that overlapping classes can never be established in the realm of taxation except at the price of an infringement of the federal constitution. The recognition of such a rule means that a department store may not be taxed on the net receipts of its business unless all the many activities thus brought under a single roof are taxed in the same way when separately conducted. . . . There must be a tax on the business of the draper, the jeweler, the shoemaker, the hatter, the carpet dealer and what not. For the same reason the proprietor of a retail market dealing in meats and groceries and vegetables and fruits will then escape, at least proportionately, a tax upon receipts if the statute does not cover the business of the shopkeeper who derives a modest income from the sale of peanuts and bananas. There are few taxes upon earnings that would pass so fine a sieve. The rule, if there is any, against the creation of overlapping classes for purposes of taxation is manifestly not one of general validity. The range of its application must depend upon the facts." 10

"The rule is elementary that a state in adopting a system of taxation is not confined to a formula of rigid uniformity. . . . It may tax some kinds of property at one rate, and others at another, and exempt others altogether. ... It may lay an excise on the operations of a particular kind of business, and exempt some other hind of business closely akin thereto. ... What is true of division into classes according to subject matter must be true of division into classes dependent upon time. The temporal arrangement must have its origin, to be sure, in something more

${ }^{16}$ Concordia Ins. Co. v. Illinois, 292 U. S. 535, 554-55 (1934) (dissenting).

95 COL.

YALE 465

HARV. 447 
than ... a tyrannical exhibition of arbitrary power. If that reproach has been avoided, the classification does not fail because the burdens before and after are not always and everywhere in perfect equilibrium.

"From all this it follows that a distinction between wills or deeds effective before 1907 and those effective afterwards - the exercise or non-exercise of powers under instruments of the first class giving rise to a succession to be taxed as a bequest from the donee, and the exercise or non-exercise of powers under instruments of the second class to be taxed as a bequest from the donor - is not rooted in caprice. The point of time which separates the classes is not interjected arbitrarily or by an exertion of brute force, but corresponds to the behests of a rational taxonomy. . . . A legislature cannot be expected in drafting legislation to think out every conceivable situation in which the members of one class will bear a heavier burden than the members of another. . . . Eccentricities of incidence are common, and perhaps inevitable, in every system of taxation. The future would have to be scanned with microscopical powers of vision to foresee and forestall every possible diversity. For present purposes it is enough that the order of events removes the stigma of caprice from a system of classification whereby donees of a power before the passage of the act are treated as grantors, the tax to be laid upon that basis, whereas donors of a power are recognized as the source of the succession in respect of transfers afterwards." 17

Taxation primarily for revenue can hardly exclude social consequences. The complexities of tax legislation are intensified whenever social policy is its predominant aim. From the day of Hamilton's Report on Manufactures, American statesmen have employed taxation for purposes other than revenue. Beginning with Theodore Roosevelt's administration, taxation has assumed a mounting share in the process of social adjustment. "A motive to build up through legislation the quality of men," Cardozo was allowed to say for a narrow majority of the Court, "may be as creditable in the thought of some as a motive to magnify the quantity of trade. Courts do not choose between such values in adjudging legislative powers. They put the choice aside as beyond their lawful competence. . . . The tax now assailed may have its roots in an erroneous conception of the ills of the body

17 Binney v. Long, 299 U. S. 280, 297-99 (I936) (dissenting).

448 HARV.

466 YALE

cot. 96 
politic or of the efficacy of such a measure to bring about a cure. We have no thought in anything we have written to declare it expedient or even just, or for that matter to declare the contrary. We deal with power only." 18

Thus, various forms of exaction have been devised as one response to the problems presented by economic concentration. Whether to differentiate between big and smaller business, and how to do so - these are questions which divide expert as well as lay opinion. It is not disrespectful for a lawyer to suggest that this is a realm of public finance in which the fog of doubt and confusion has not yet been wholly lifted by economists. That nevertheless this is a field into which the state may enter no one will deny. And yet there is no legal litmus to give ready answers when state action is challenged. Again the ultimate canons for constitutional construction must do service. The Constitution does not have preferences between competing theories, and the wide range of discretion which this leaves to the legislative judgment must not be curtailed by judicial intrusion, under the guise of abstract absolutes, into the domain of policy. By Cardozo these generalities were translated into living practice. For he viewed measures of social taxation with a shrewd eye for actuality undiverted by hypothesized unrealities:

"Statistics . . . indicate that there is a definite line of cleavage between chains that serve consumers within a single territorial unit and those framed for larger ends. The business that keeps at home affects the social organism in ways that differ widely from those typical of a business that goes out into the world. It affects the social organism, but also it affects itself. With the lengthening of the chain there are new fields to be exploited. The door is open to opportunities that have hitherto been closed. Where does the local have an end and the nonlocal a beginning? The legislature had to draw the line somewhere, and it drew it with the county. Within the range of reasonable discretion its judgment must prevail.

“. . . Lawmakers are not required to legislate with an eye to exceptional conditions. Their search is for probabilities and tendencies of general validity, and these being ascertained, they may frame their rule accordingly. They are not required to legislate with an eye to forms

18 Fox v. Standard Oil Co., 294 U. S. 87, 100-0r (r935).

97 COL.

YALE 467

HARV. 449 
of growth beyond the limits of their own state. In laying a tax upon a Florida chain their concern is with those activities that have social and economic consequences for Florida and her people. The question for them, and so for us, is not how a business might be expected to develop if its forms and lines of growth were to be predicted in the abstract without reference to experience. The question is how it docs develop in normal or average conditions, and the answer to that question is to be found in life and history.

". . . It will not do to shut one's eyes to the motive that has led so many legislatures to lay hold of this difference [between integrated and voluntary chains] and turn it into a basis for a new system of taxation. The system has had its origin in the belief that the social utility or inutility of one group is less or greater than that of others, and that the choice of subjects to be taxed should be adjusted to social gains and losses. Courts would be lacking in candor if they were not to concede the presence of such a motive behind this chain store legislation. But a purpose to bear more heavily on one class than another will not avail without more to condemn a tax as void. . . . We must know why the discrimination is desired, to what end it is directed and the relation between end and means. If the motive is vindictiveness, ensuing in mere oppression, the result may be one thing. If the motive and the end attained are the advancement of the public good, the result may be quite another, unless preference and repression go so far as to outrun the bounds of reason. The legislature has determined with the approval of the court that an integrated chain is a taxable class separable from independent dealers and even from chains that are merely coöperative leagues. If these differences suffice to establish a basis for distinction between a tax and none at all, smaller differences may suffice for the graduation of the scale. The legislature has found them in those variations of degree that separate a chain within the territorial unit of the locality from chains that are reaching out for wider fields of power. There is no need to approve or disapprove the concept of utility or inutility reflected in such laws. . . . The concept may be right or wrong. At least it corresponds to an intelligible belief, and one widely prevalent today among honest men and women. ... With that our function ends." ${ }^{19}$

The bite of a tax case, as of a tax measure, is in its particular circumstances. Fair-sounding generalities too often shelter concrete evasions of them. And so, only detailed analysis of a tax

19 Liggett Co. v. Lee, 288 U. S. 517, 581-\$6 (1933) (dissenting).

$45^{\circ}$ HARV.

468 YALE

COL. 98 
like that involved in Stewart Dry Goods Co. v. Lewis ${ }^{20}$ - its economic setting, its practical operations, and the hopes and fears that it expressed - could give an adequate critique of the meaning of the decision, of its relation to antecedent authorities and of the clash of intellectual procedures which, from the same precedents and precepts, drew opposite conclusions. Cardozo's dissent in this case has such organic unity that one can hardly avoid mutilation in brief excerpts:

"The prevailing opinion commits the court to a holding that a tax upon gross sales, if laid upon a graduated basis, is always and inevitably a denial of the equal protection of the laws, no matter how slight the gradient or moderate the tax. . . .

"The question then is whether there is rationality in the belief that capacity to pay increases, by and large, with an increase of receipts. Certain it is that merchants have faith in such a correspondence and act upon that faith. ...

". . . Larger and larger sales are sought for by business and sought for with avidity. They are not the products of whim and fancy. They represent a conception of probabilities and tendencies confirmed by long experience. The conception is no more arbitrary in the brain of a government official than it is in the mind of a company director. . . .

"The framers of a system of taxation may properly give heed to convenience of administration, and in the search for that good may content themselves with rough and ready compromises. Elaborate machinery, designed to bring about a perfect equilibrium between benefit and burden, may at times defeat its aim through its own elaboration. A crippling result of the decision just announced will be to restrict the choice of means within bounds unreasonably narrow. Hereafter in the tasation of business a legislature will be confined, it seems, to an income or profit tax if it wishes to establish a graduated system proportioning burden to capacity. But profits themselves are not susceptible of ascertainment with certainty and precision except as the result of inquiries too minute to be practicable. The returns of the taxpayer call for an exercise of judgment as well as for a transcript of the figures on his books. They are subject to possible inaccuracies, almost without number. Salaries of superintendents, figuring as expenses, may have been swollen inordinately; appraisals of plant, of merchandise, of patents, of what not, may be erroneous or even fraudulent. ... These difficulties and dangers

20294 U. S. 550 (1935).

99 COL.

YALE 469

EARV. 45 I 
bear witness to the misfortune of forcing methods of taxation within a Procrustean formula. If the state discerns in business operations uniformities and averages that seem to point the way to a system ensier to administer than one based upon a report of profits, and yet likely in the long run to work out approximate equality, it ought not to be denied the power to frame its laws accordingly.

"For answer to all this the thrust will not avail that 'it is difficult to be just and easy to be arbitrary.' The derogatory epithet assumes the point to be decided. There is nothing arbitrary in rescuing a vast body of taxpayers from the labor and expense of preparing elaborate reports, at best approximately accurate. There is nothing arbitrary in rescuing a government from the labor and expense of setting up the huge and unwieldy machinery of an income tax department with a swarm of investigators and accountants and legal and financial experts. To frame a system of taxation in avoidance of evils such as these is no act of sheer oppression, no abandonment of reason, no exercise of the general will in a perverse or vengeful spirit." ${ }^{21}$

A healthy society is as much dependent upon wise price policies as upon sound systems of taxation. But the puzzles of a proper price mechanism are perhaps even less amenable to unequivocal solutions than are ways for achieving appropriate fiscal measures. The operation of pricing schemes in the market is very different from what it appears to be in economic treatises. Not the least of these perplexities is the influence of governmental intervention in pricing. It is more than sixty years since the Supreme Court gave sanction to price regulation within the limited field of "public callings." ${ }^{22}$ Yet even within this circumscribed field confusion and friction, with resulting waste, have been more prominent than agreement on procedure and criteria for fixing values and rates. ${ }^{33}$ But in this area of government no less than in that of taxation, legislation cannot wait for accord among economists or general acceptance of their theories. Powerful economic forces produce problems which must be dealt with by legislators with whatever fallible and tentative wisdom they can utilize. The competing

21 Id. at 566-77.

22 Munn v. Illinois, 94 U. S. 113 (1877); cf. dissent of Holmes, J., in Tyson \& Bro. v. Banton, 273 U. S. $4 \mathrm{I} 8,445$ (1927).

23 See Frankfurter, The Public and Its Governnant (I930) Lecture III, p. $8 \mathrm{r}$. 
claims of consumers and producers, of large producers and small, of large consumers and small, of producers and distributors, of distributors and consumers, press for adjustment. Fallible wisdom produces fallible legislation. To deny government the right to act except with omniscience and prescience is to deny it the right to act at all.

The right to act is evolving empirically and waveringly." In dealing with these new exertions of governmental power, as where he concerned himself with novel methods of taxation, Cardozo found his bearings in loyal adherence to the classic doctrines for constitutional adjudication. He sharply differentiated the austere responsibility of a judge from the ample discretion of the legislator. He found no barriers to legislative recognition of differences among different industries or among different groups within the same industry; he found no warrant for any doctrine that afforded greater immunity to the price mechanisms of industry than to its other aspects.

That the requirement of due process raises no barrier to pricefixing where "the conditions or practices of an industry " justify such a regulatory system was apparently established in Nebbia's ${ }^{25}$ case. But two years later the provisions of the Guffey Act ${ }^{26}$ foundered on the rock of inseparability against the protest of the Chief Justice and that of Brandeis, Stone and Cardozo, JJ. ${ }^{.7}$ This impressive minority found the price controls separable from the rest of the Act and as such within the doctrine of Ncbbia's case. That a single decision, reached by a slender majority in a strongly contested field, does not guarantee security for a doctrine, is illustrated by the need which Cardozo felt to argue the legislative power of price-fixing under circumstances like those presented by the record in the Carter case.

Referring to "the conditions and practices" found in $\mathrm{Neb}$ -

24 See Frankfurter and Fisher, The Business of the Supreme Court at the October Terms, 1935 and 1936 (1938) 51 HaRv. L. REv. 577, 633-37.

25 Nebbia v. New York, 29r U. S. 502 (1934).

26 The Bituminous Coal Conservation Act of 1935, 49 SrAT. 991.

27 Carter v. Carter Coal Co., 298 U. S. 238 (r936). The separate opinion of the Chief Justice appears at 3 I7. Mr. Justice Cardozo spoke for Brandeis and Stone, JJ., as well as for himself, at $\mathbf{3 2 4}$.

IOI COL. 
bia's case to justify price-fixing in the New York milk industry, Cardozo proceeded:

"All this may be said, and with equal, if not greater force, of the conditions and practices in the bituminous coal industry, not only at the enactment of this statute in August, I935, but for many years before. Overproduction was at a point where free competition had been degraded into anarchy. Prices had been cut so low that profit had become impossible for all except the lucky handful. Wages came down along with prices and with profits. There were strikes, at times nation-wide in extent, at other times spreading over broad areas and many mines with the accompaniment of violence and bloodshed and misery and bitter feeling. The sordid tale is unfolded in many a document and treatise. During the twenty-three years between 1913 and 1935 , there were rineteen investigations or hearings by Congress or by specially created commissions with reference to conditions in the coal mines. The hope of betterment was faint unless the industry could be subjected to the compulsion of a code. In the weeks immediately preceding the passage of this Act the country was threatened once more with a strike of ominous proportions. The plight of the industry was not merely a menace to owners and to mine workers: it was and had long been a menace to the public, deeply concerned in a steady and uniform supply of a fuel so vital to the national economy.

"Congress was not condemned to inaction in the face of price wars and wage wars so pregnant with disaster. Commerce had been choked and burdened; its normal flow had been diverted from one state to another; there had been bankruptcy and waste and ruin alike for capital and for labor. The liberty protected by the Fifth Amendment does not include the right to persist in this anarchic riot. . . . The free competition so often figured as a social good imports order and moderation and a decent regard for the welfare of the group. . . . There is testimony in these records, testimony even by the assailants of the statute, that only through a system of regulated prices can the industry be stabilized and set upon the road of orderly and peaceful progress. . . . After making every allowance for difference of opinion as to the most efficient cure, the student of the subject is confronted with the indisputable truth that there were ills to be corrected, and ills that had a direct relation to the maintenance of commerce among the states without friction or diversion. An evil existing, and also the power to correct it, the lawmakers were at liberty to use their own discretion in the selection of the means." ${ }^{2 \mathrm{~s}}$

28298 U. S. at 330-32.

454 HARV.

472 YALE

COL. IO2 
Never was judicial utterance more felicitously chosen than when Marshall characterized the power of courts to sit in judgment upon legislatures as a "delicate" function. How fine the threads by which the Supreme Court weaves its share in the texture of government is beautifully illustrated by the series of cases in which the Court passed upon the New York Milk Control Act. In Nebbia's case, as we have seen, the Court over vigorous protest found no restraint in the Federal Constitution against fixing the selling price of milk. In the same year the Court sustained an order under the New York statute, fixing a minimum price to be paid to producers as well as a minimum resale price, against the claim of a dealer that under this order he would be operating at a loss. " "The appellant's grievance amounts to this," wrote Mr. Justice Cardozo for the Court, "that it is operating at a loss, though other dealers more efficient or economical or better known to the public may be operating at a profit." "o Little indulgence was given to such a grievance. "The Fourteenth Amendment does not protect a business against the hazards of competition." In Borden's Co. v. Ten Eyck ${ }^{31}$ the Court, again dividing as it did in Nebbia's case, sustained a subordinate feature of the New York milk control system allowing a differential in the selling price of milk between dealers who had and dealers who did not have welladvertised trade names. The very same day a majority of the Court declared invalid another provision of the New York Act discriminating between milk dealers without well-advertised trade names who were in the business before April ro, I933, and those in that class who entered it later. ${ }^{32}$ Against this conclusion Brandeis, Stone and Cardozo, JJ., entered dissent. How tenuous was the margin of difference between these cases is attested by the robust sentence opening Cardozo's dissenting opinion: "The judgment just announced is irreconcilable in principle with the judgment in Borden's case, ante, p. 25I, announced a minute or so earlier." ${ }^{33}$

The whole of Cardozo's closely-knit dissent in this case illus-

29 Hegeman Farms Corp. v. Baldwin, 293 U. S. 163 (1934).

$30 \mathrm{Id}$. at 170.

31297 U. S. 251 (1936).

32 Mayflower Farms v. Ten Eyck, 297 U. S. 266 (1936). 33 Id. at 274.

IO3 COL.

YAIE 473

HARV. 455 
trates the treacherous appearance of law given to issues essentially of fact that come before the Court for judgment under the due process clauses. It also illustrates the rigor with which Cardozo pursued the Holmesian tradition of not allowing questions of degree, however close, to be elevated into constitutional principles:

"A minimum price for fluid milk was fixed by law in April, x933. At that time, ' independents' were underselling their competitors, the dealers in well-advertised brands, by approximately a cent a quart. There was reason to believe that unless that differential was preserved, they would be driven out of business. To give them an opportunity to survive, the lawmakers maintained the differential in the City of New York, the field of keenest competition. We bave learned from the opinion in Borden's case that this might lawfully be done.

"The problem was then forced upon the lawmakers, what were to be the privileges of independents who came upon the scene thereafter? . . .

"Hardships, great or little, were inevitable, whether the field of the differential was narrowed or enlarged. The legislature, and not the court, has been charged with the duty of determining their comparative extent. ... In declaring the equities of newcomers to be not inferior to those of others, the judgment makes a choice between competing considerations of policy and fairness, however emphatic its professions that it applies a rule of law.

"For the situation was one to tax the wisdom of the wisest. At the very least it was a situation where thoughtful and honest men might see their duty differently. . . .

". . . It is juggling with words to say that all the independents make up a single 'class,' and by reason of that fact must be subjected to a single rule. Whether the class is divisible into subclasses is the very question to be answered. There may be division and subdivision unless separation can be found to be so void of rationality as to be the expression of a whim rather than an exercise of judgment. ... On this occasion, happily, the facts are not obscure. Big dealers and little ones, newcomers in the trade and veterans, were clamorously asserting to the legislature their title to its favor. I have not seen the judicial scales so delicately poised and so accurately graduated as to balance and record the subtleties of all these rival equities, and make them ponderable and legible beyond a reasonable doubt.

"To say that the statute is not void beyond a reasonable doubt is to say that it is valid." 34

\section{Id. at $275-78$.}

$45^{6}$ HARV.

474 YALE

Cor. 104 


\section{III}

The ample scope which Cardozo thus gave to legislative discretion in devising policy did not make him indifferent to those procedural safeguards in the exercise of governmental powers which give historic basis to "due process." ${ }^{3}$ Prices may be fixed and profits limited, certainly for the "public callings," but not without fair inquiry and an adequate canvass of the factors relevant to adjustment between private and public interests:

"The fundamentals of a trial were denied to the appellant when rates previously collected were ordered to be refunded upon the strength of evidential facts not spread upon the record.

"The Commission had given notice that the value of the property would be fixed as of a date certain. . . . Without warning or even the hint of warning that the case would be considered or determined upon any other basis than the evidence submitted, the Commission cut down the values for the years after the date certain upon the strength of information secretly collected and never yet disclosed. The company protested. It asked disclosure of the documents indicative of price trends, and an opportunity to examine them, to analyze them, to explain and rebut them. The response was a curt refusal. Upon the strength of these unknown documents refunds have been ordered for sums mounting into millions, the Commission reporting its conclusion, but not the underlying proofs. The putative debtor does not know the proofs today. This is not the fair hearing essential to due process. It is condemnation vithout trial." 36

The accomplishments of half a century have won for the Interstate Commerce Commission a place in the Supreme Court's esteem not second to that accorded the lower federal courts. Mr. Justice Cardozo gave voice to that esteem:

"The structure of a rate schedule calls in peculiar measure for the use of that enlightened judgment which the Commission by training and experience is qualified to form. . . . It is not the province of a court to absorb this function to itself. . . . The judicial function is exhausted

35 Shattuck, The True Mraning of the Term "Liberty" in Those Clauses in the Federal and State Constitutions IVhich Protect "Life, Liberty, and Property" (IS9r) ${ }_{4}$ HARv. L. REv. 365.

${ }^{36}$ Ohio Bell Tel. Co. v. Comm., 301 U. S. 292, 300 (1937).

IO5 COL. 
when there is found to be a rational basis for the conclusions approved by the administrative body. In this instance the care and patience with which the Commission fulfilled its appointed tasks are plain, even to the casual reader, upon the face of its report." ${ }^{37}$

But the very complexity of the technical tasks entrusted to such a commission led to the requirement that it formulate the basis of its determinations. This is the justification for findings, that they serve to illumine and thereby to safeguard the Commission's own procedures. It was not in the spirit of Baron Parke that Cardozo spoke for the Court in vindicating the rationale of findings:

"We would not be understood as saying that there do not lurk in this report phrases or sentences suggestive of a different meaning. One gains at places the impression that the Commission looked upon the proposed reduction as something more than a disruptive tendency; that it found unfairness in the old relation of parity between Brazil and Springfield; and that the new schedule in its judgment would confirm Milwaukee in the enjoyment of an undue proportion of the traffic. The difficulty is that it has not said so with the simplicity and clearness through which a halting impression ripens into reasonable certitude. In the end we are left to spell out, to argue, to choose between conflicting inferences. . . . We must know what a decision means before the duty becomes ours to say whether it is right or wrong." 88

But insistence on procedural regularity was not, for Cardozo, an expression of inhospitality to the process behind the development of administrative law. Nor did he see administrative law as a collection of explicit rules uniformly applicable throughout the domain of what the British call "delegated legislation." Cardozo recognized that the broad concepts of hearing, findings and judicial review summarized a variety of diversified situations in which the large aims expressed by these concepts were variously achieved:

"We are not unmindful of cases in which the word 'hearing' as applied to administrative proceedings has been thought to have a bronder meaning. All depends upon the context. . . . The answer will not be

37 Mississippi Valley Barge Co. v. United States, 292 U. S. 282, 286-87 (1934).

38 United States v. Chicago, M., St. P. \& P. R. R., 294 U. S. 499, $510-11$ (1935). $45^{8}$ HARV. 476 YALE c0L. 106 
found in definitions of a hearing lifted from their setting and then applied to new conditions. The answer will be found in a consideration of the ends to be achieved in the particular conditions that were espected or foreseen. To know what they are, there must be recourse to all the aids available in the process of construction, to history and analogy and practice as well as to the dictionary." 30

Cardozo had, if not Maitland's genius, the latter's perception of the social forces that mold law. ${ }^{20}$ He had, to be sure, an enormous fund of technical learning. But he escaped that dangerous narrowness of the mere legal pedant which has been the subject of classic animadversions by Burke ${ }^{11}$ and Bagehot." He did so by seeing law as part of our whole cultural history. Cardozo was not imprisoned by the tags and rags of learning, for he was guided by understanding of the circumstances summarized in historic clichés and by philosophic insight into their significance. Thus he never forgot that forms are related to functions; that court procedures not expressive of ultimate liberties are not necessarily norms of universal applicability; that practices of administration may have a momentum of rationality; and that activities of government which are not the immediate province of courts ought not to be circumscribed by formalities historically appropriate to courts. ${ }^{43}$ He used his learning in technical law not as the standard for judgment of allowable development in new branches of the law, but as a fertile source for proving that old principles have creative energies for new situations. ${ }^{44}$

Thus viewing administrative law, Cardozo eschewed unreal abstractions ${ }^{45}$ and stuck close to the practicalities of government as

39 Norwegian Nitrogen Co. v. United States, 288 U. S. 294, 3I7 (r933) (dealing with procedure of the Tariff Commission under the Revenue Act of 1922).

40 Cf. Matrland, Constitutional History of Exgland (1913) 415 ct seq.

41 See Letter to the Sheriffs of Bristol, 2 Burke, Works (3d ed. I86g) Ig6 ef seq.

42 See Bagehot's portrait of Lord Eldon in Tlte First Edinburgh Revicurers in 2 Barrongton, Works aNd LIFE OF WaLter B.agerot (19r5) $56 \mathrm{ct} \mathrm{seq.}$

43 United States v. Henry Prentiss \& Co., 288 U. S. 73 (1933); Bemis Bro. Bag Co. v. United States, 289 U. S. 28 (rg33).

44 See Bemis Bro. Bag. Co. v. United States, 289 U. S. 28, 33 (1933).

45 "Abstraction, though necessary to thought, is liable to be the death of it. It lures the more guileless of its devotees into solemn futilities. . .." R. H. Tawncy, Book Review (r938) i6 THE New Statesaran and Natrow (N.S.) sSo-Sz. 
revealed by history, by legislative ends and administrative responsibilities:

"The opinion of the court reminds us of the dangers that wait upon the abuse of power by officialdom unchained. The warning is so fratght with truth that it can never be untimely. But timely too is the reminder, as a host of impoverished investors would be ready to attest, that there are dangers in untruths and half truths when certificates masquernding as securities pass current in the market. There are dangers in spreading a belief that untruths and half truths, designed to be passed on for the guidance of confiding buyers, are to be ranked as peccadillos, or even perhaps as part of the amenities of business. When wrongs such as these have been committed or attempted, they must be dragged to light and pilloried. To permit an offending registrant to stifle an inquiry by precipitate retreat on the eve of his exposure is to give immunity to gutilt; to encourage falsehood and evasion; to invite the cunning and unscrupulous to gamble with detection. If withdrawal without leave may check investigation before securities have been issued, it may do as much thereafter, unless indeed consistency be thrown to the winds, for by the teaching of the decision withdrawal without leave is equivalent to a stop order, with the result that forthwith there is nothing to investigate. The statute and its sanctions became the sport of clever knaves.

"Appeal is vaguely made to some constitutional immunity, whether express or implied is not stated with distinctness. . . . If the immunity rests upon some express provision of the Constitution, the opinion of the court does not point us to the article or section. If its source is to be found in some impalpable essence, the spirit of the Constitution or the philosophy of government favored by the Fathers, one may take leave to deny that there is anything in that philosophy or spirit whereby the signer of a statement filed with a regulatory body to induce official action is protected against inquiry into his own purpose to deceive. The argument for immunity lays hold of strange analogies. A Commission which is without coercive powers, which cannot arrest or amerce or imprison though a crime has been uncovered, or even punish for contempt, but can only inquire and report, the propriety of every question in the course of the inquiry being subject to the supervision of the ordinary courts of justice, is likened with denunciatory fervor to the Star Chamber of the Stuarts. Historians may find hyperbole in the sanguinary simile." 40

46 Jones v. SEC, 298 U. S. I, 32-33 (1936) (dissenting). 


\section{IV}

In the domain of economic affairs, the penumbral region where law and policy blend, Cardozo walked humbly. But when those ethical precepts which are embodied in the Bill of Rights were invoked, he responded with all the certitude of one whose most constant companion was reason and whose life was rooted in the moral law. Unfortunately, the brevity of his tenure and the contingencies upon which the assignment of opinions depends gave him only limited opportunity in Washington to express with new vitality the claims of civilization expressed by constitutional protection to civil liberties. Doubtless his presence on the Court, particularly in these matters, made itself felt otherwise than through his own opinions. For, while the conferences in Washington could hardly have had for Cardozo the intimate camaraderie which so gladdened his days at Albany, the contagion of his ethical qualities must have affected the currents of his newer associations. To trace such influences upon the actions and opinions of others is, however, too elusive a pursuit for one outside the inner mysteries of the Court.

We do not therefore have in his Supreme Court opinions such full-bodied expression of his philosophy of spiritual freedom as that which opportunities enabled Holmes to add to our permanent literature. ${ }^{47}$ Happily, however, he wrote on the great theme of

47 Friendly critics have suggested that Cardozo viewed encroachments upon civil liberties with less deference to the legislative judgment than that which he accorded to economic measures. The same seeming inconsistency has been suggested against Holmes, and the answer made in Holmes' case applies to Cardozo as well:

"The Justice deferred so abundantly to legislative judgment on economic policy because he was profoundly aware of the extent to which social arrangements are conditioned by time and circumstances, and of how fragile, in scientific proof, is the ultimate validity of a particular economic adjustment. He knew that there was no authoritative fund of social misdom to be drawn upon for answers to the perplexities which vast new material resources had brought. And so he was hesitant to oppose his own opinion to the economic viems of the legislature. But history bad also taught him that, since social development is a process of trial and error, the fullest possible opportunity for the free play of the human mind was an indispensable prerequisite. Since the history of civilization is in considerable measure the displacement of error which once held sway as official truth by belicis which in turn have yielded to other truths, the liberty of man to search for truth was of a difierent

IOg COL.

YALE 479

HARV. 461 
the freedom of the human mind in perduring language to which not even an opinion could have added intrinsic authority:

"Many an appeal to freedom is the masquerade of privilege or inequality seeking to intrench itself behind the catchword of a principle. There must be give and take at many points, allowance must be made for the play of the machine, or in the clash of jarring rivalries the pretending absolutes will destroy themselves and ordered freedom too. Only in one field is compromise to be excluded, or kept within the narrowest limits. There shall be no compromise of the freedom to think one's thoughts and speak them, except at those extreme borders where thought merges into action. There is to be no compromise here, for thought freely communicated, if I may borrow my own words, is the indispensable condition of intelligent experimentation, the one test of its validity. There is no freedom without choice, and there is no choice without knowledge or none that is not illusory. Here are goods to be conserved, however great the seeming sacrifice. We may not squander the thought that will be the inheritance of the ages." 48

In at least one case - the last opinion he delivered in person he had to consider judicially the scope of the civil liberties protected by the Constitution. He did so in order to discover a " unifying principle," if possible, in those cases in which the Bill of Rights or its embodiment in the Fourteenth Amendment had been invoked. It is a superb example of his strict adherence to the common-law tradition - especially important in constitutional controversies - of dealing with the concrete case, but dealing with it not in the shallow belief that a case is a discrete phe-

order than some economic dogma defined as a sacred right because the temporal nature of its origin had been forgotten. And without freedom of expression, liberty of thought is a mockery. Nor can truth be pursued in an atmosphere hostile to the endeavor or under dangers which only heroes hazard.

"Naturally, therefore, Mr. Justice Holmes attributcd very different legal significance to those liberties of the individual which history has attested as the indispensable conditions of a free society from that which he attached to libertics which derived merely from shifting economic arrangements. ... Because these civil liberties were explicitly safeguarded in the Constitution or conceived to be basic to any notion of the liberty guaranteed by the Fourteenth Amendment, Mr. Justico Holmes was far more ready to find legislative invasion in this ficld than in the aret of debatable economic reform." Frankfurter, Mr. Justice Holares and Tite SuPREME COURT (1938) 50-5I.

48 Cardozo, Mr. Justice Holmes (193r) 44 HaRv. L. REv. 682, 687-88.

462 HARV.

480 YALE

COL. IIO 
nomenon having neither genealogy nor offspring, but in the vivid awareness that the specific inevitably implicates principles and premises:

"The exclusion of these immunities and privileges [in cases cited] from the privileges and immunities protected against the action of the states has not been arbitrary or casual. It has been dictated by a study and appreciation of the meaning, the essential implications, of liberty itself.

"We reach a different plane of social and moral values when we pass to the privileges and immunities that have been taken over from the earlier articles of the federal bill of rights and brought within the Fourteenth Amendment by a process of absorption. These in their origin were effective against the federal government alone. If the Fourteenth Amendment has absorbed them, the process of absorption has had its source in the belief that neither liberty nor justice would exist if they were sacrificed. . . . This is true, for illustration, of freedom of thought, and speech. Of that freedom one may say that it is the matrix, the indispensable condition, of nearly every other form of freedom. With rare aberrations a pervasive recognition of that truth can be traced in our history, political and legal. So it has come about that the domain of liberty, withdrawn by the Fourteenth Amendment from encroachment by the states, has been enlarged by latter-day judgments to include liberty of the mind as well as liberty of action. The extension became, indeed, a logical imperative when once it was recognized, as long ago it was, that liberty is something more than exemption from physical restraint, and that even in the field of substantive rights and duties the legislative judgment, if oppressive and arbitrary, may be overridden by the courts." 40

Human interests of such dignity he would not imprison in the subtle meshes of procedural technicality. He was alert against the dangers of concessions in principle but attritions in practice. "A system of procedure is perverted from its proper function when it multiplies impediments to justice without the warrant of clear necessity." so Thus he wrote in a little case between man and man. Naturally, therefore, this master of procedure refused to be hobbled by the Court's contrivances for the orderly presentation of appeals, when a vital issue of freedom of speech appeared from the record as clearly and as opportunely as the

49 Palko v. Connecticut, 302 U. S. 319, 326-27 (1937).

5o Reed v. Allen, 286 U. S. rgr, 209 (r932) (dissenting).

III COL.

YALE $4 S I$

HARV. 463 
strange circumstances of the Herndon case ${ }^{\text {bt }}$ permitted. Again, no one knew better than he the rational limits of our system of evidence, but he also knew the reaches of its utility in protecting life from human caprice and fallibility. Consequently he was alert against the risks of overrefinement in rules to be applied by the men and women who sit in the jury-box, particularly when life is in the balance. ${ }^{52}$

Civil liberties were for Cardozo not empty slogans but cherished protections of the human spirit. They derived meaning from history and were given pertinence by contemporary society. He was, however, too steeped in the history of the law not to detect quickly meretricious uses of history. By seeing decisions like that in Bushell's case in their setting, he adhered to a principle without distorting it to alien purposes. ${ }^{\text {[3 }}$ And so he never rested

51 "I hold the view that the protection of the Constitution was seasonably invoked and that the court should proceed to an adjudication of the merits. Where the merits lie I do not now consider, for in the view of the majority the merits are irrelevant. My protest is confined to the disclaimer of jurisdiction. . . .

"What was brought into the case on the motion of rehearing was a standard wholly novel, the expectancy of life to be ascribed to the persuasivo power of an idea. The defendant had no opportunity in the state court to prepare his argumont accordingly. He had no opportunity to argue from the record that guilt was not a reasonable inference or one permitted by the Constitution, on the basis of that test any more than on the basis of others discarded as unfitting. . . . The argumont thus shut out is submitted to us now. Will men 'judging in calmness' . . . say of the defendant's conduct as shown forth in the pages of this record that it was an attempt to stir up revolution through the power of his persuasion and within the time when that persuasion might be expected to endure? If men so judging will say yes, will the Constitution of the United States uphold a reading of the statute that will lead to that response? Those are the questions that the defendant lays before us after conviction of a crime punishable by death in the discretion of the jury. I think he should receive an answer." Herndon v. Georgia, 295 U. S. 441, 447, 454-55 (I935) (dissenting).

52 "Discrimination so subtle is a feat beyond the compass of ordinary minds. The reverberating clang of those accusatory words would drown all weaker sounds. It is for ordinary minds, and not for psychoanalysts, that our rules of evidence are framed. They have their source very often in considerations of administrative convenience, of practical expediency, and not in rules of logic. When the risk of confusion is so great as to upset the balance of advantage, the evidence goes out." Shepard v. United States, 2go U. S. 96, 104 (1933).

53 "Nothing in our decision impairs the authority of Bushell's case, Vaughan I35, 1670 , with its historic vindication of the privilege of jurors to return a verdict freely according to their conscience. . . B Bushell's case was born of the fear of the Star Chamber and of the tyranny of the Stuarts. . . . It stands for a great prin- 
on a formula, even one that embodied the most precious victory of reason. Had Cardozo ever been called upon to vindicate the security which the Constitution guarantees to "the free exercise" of religion, he doubtless would have done so in majestic utterance. But when immunity from compulsory instruction in military science in a state university sought the shelter of religious liberty, he rejected the claim sympathetically but robustly:

"The petitioners have not been required to bear arms for any hostile purpose, offensive or defensive, either now or in the future. They have not even been required in any absolute or peremptory way to join in courses of instruction that will fit them to bear arms. If they elect to resort to an institution for higher education maintained with the state's moneys, then and only then they are commanded to follow courses of instruction believed by the state to be vital to its welfare. This may be condemned by some as unwise or illiberal or unfair when there is violence to conscientious scruples, either religious or merely ethical. More must be shown to set the ordinance at naught. . . . Instruction in military science is not instruction in the practice or tenets of a religion. Neither directly nor indirectly is government establishing a state religion when it insists upon such training. Instruction in military science, unaccompanied here by any pledge of military service, is not an interference by the state with the free exercise of religion when the liberties of the constitution are read in the light of a century and a half of history during days of peace and war." 54

\section{V}

The constitutional history of our federal system as disclosed in Supreme Court decisions is in no small measure the still unwritten story of the rhythm of emphasis now upon national power, now upon state power. But no period of the Court's life contained such extreme fluctuations of rhythm within so short a span as the less than six terms during which Cardozo sat.

Certainly constitutional dialectic has never been employed to

ciple, which is not to be whittled down or sacrificed. On the other hand it is not to be strained and distorted into fanciful extensions. There is a peril of corruption in these days which is surely no less than the peril of cocrcion." Clark v. United States, 289 U. S. I, 16-I7 (I933).

54 Hamilton v. Regents, 293 U. S. 245, 265-66 (r934) (concurring).

II3 COL.

YALE 483

HARV. 465 
more self-defeating ends than when a narrow majority of the Court invoked state sovereignty against the Municipal Bankruptcy Act as a means of destroying the state's freedom of action. Such a doctrine of impotence, Cardozo protested, was consonant neither with reason nor with the whole " evolutionary process" of our constitutional law:

"The question is not here whether the statute would be valid if it made provision for involuntary bankruptcy, dispensing with the consent of the state and with that of the bankrupt subdivision. For present purposes one may assume that there would be in such conditions a dislocation of that balance between the powers of the states and the powers of the central government which is essential to our federal system. . . . The statute now in question does not dislocate the balance. It has been framed with sedulous regard to the structure of the federal system. The governmental units of the state may not act under this statute except through the medium of a voluntary petition which will evince their own consent, their own submission to the judicial power. Even that however is not enough. . . . To cap the protective structure, Texas has a statute whereby all municipalities, political subdivisions and taxing districts in the state are empowered to proceed under the challenged Act of Congress, and to do anything appropriate to take advantage of its provisions. . . .

". . . To hold that this purpose [relief for distressed municipalities] must be thwarted by the courts because of a supposed affront to the dignity of a state, though the state disclaims the affront and is doing all it can to keep the law alive, is to make dignity a doubtful blessing." io

This conception of the federal system became the law of the land within two years, for the dissenters in United States v. Bekins ${ }^{\text {ro }}$ were surely justified in their opinion, "that the principle approved in Ashton v. Cameron County District" was controlling in the Bekins case if that principle had vitality.

Within a year after the Ashton case protected the states from federal collaboration which they sought, Mr. Justice Cardozo was permitted to speak for a majority of the Court in sustaining one of the most ramifying exertions of Federal power. For a hundred years the implications of the general welfare clause were debated

55 Ashton v. Cameron County Dist., 298 U. S. 513, 538-39, 54I (1936). 56304 U. S. 27, 54 (1938). 
by publicists and statesmen. The Supreme Court, with wise abstention, avoided this thorny conflict. Excepting only the creative interpretations of Marshall whereby great national powers were breathed into the inert words of the Constitution, probably no other adjudications of the Court initiated such far-reaching recognition of federal authority as that which was given in the Social Security cases. ${ }^{5 T}$ From such powerful and luminous opinions as those which Cardozo rendered there, the choice of short excerpts becomes an invidious necessity:

" Congress may spend money in aid of the 'general welfare.' . . . The conception of the spending power advocated by Hamilton and strongly reinforced by Story has prevailed over that of Madison, which has not been lacking in adherents. Yet difficulties are left when the power is conceded. The line must still be drawn between one welfare and another, between particular and general. Where this shall be placed cannot be known through a formula in advance of the event. There is a middle ground, or certainly a penumbra in which discretion is at large. The discretion, however, is not confided to the courts. The discretion belongs to Congress, unless the choice is clearly wrong, a display of arbitrary power, not an exercise of judgment. . . . Nor is the concept of the general welfare static. Needs that were narrow or parochial a century ago may be interwoven in our day with the well-being of the Nation. What is critical or urgent changes with the times.

"The purge of nation-wide calamity that began in r 929 has taught us many lessons. Not the least is the solidarity of interests that may once have seemed to be divided. Unemployment spreads from State to State, the hinterland now settled that in pioneer days gave an avenue of escape. . . .

"The problem is plainly national in area and dimensions. Moreover, laws of the separate states cannot deal with it effectively. Congress, at least, had a basis for that belief. . . . Only a power that is national can serve the interests of all.

"Whether wisdom or unwisdom resides in the scheme of benefits set forth in Title II, it is not for us to say. The answer to such inquiries must come from Congress, not the courts. Our concern here, as often, is with power, not with wisdom. Counsel for respondent has recalled to us the virtues of self-reliance and frugality. There is a possibility, he

57 Steward Machine Co. v. Davis, 301 U. S. 548 (1937); Helvering v. Davis, 301 U. S. 619 (1937).

II5 COL. 
says, that aid from a paternal government may sap those sturdy virtues and breed a race of weaklings. If Massachusetts so believes and shapes her laws in that conviction, must her breed of sons be changed, he asks, because some other philosophy of government finds favor in the halls of Congress. But the answer is not doubtful. One might ask with equal reason whether the system of protective tariffs is to be set aside at will in one state or another whenever local policy prefers the rule of laissez fairc. The issue is a closed one. It was fought out long ago. When money is spent to promote the general welfare, the concept of welfare or the opposite is shaped by Congress, not the states. So the concept be not arbitrary, the locality must yield." 58

Cardozo did not deem it necessary to reconcile these cases with the Butler case, ${ }^{50}$ decided fourteen months earlier, and this is not the place to make the attempt.

In these phases of our federal system Cardozo dealt with relatively novel issues which gave full play to his learning, imagination and serene devotion to the ultimate but narrowly confined function of the Court in assessing the validity of legislation. He left his special mark in every case he wrote, but when dealing with the commerce clause he wrote upon a heavily encrusted palimpsest. In view of the illumination which the Chief Justice has shed upon the organic relation of modern industry in his opinions in the Labor Board Cases, ${ }^{\circ 0}$ the earlier exposition by Cardozo of the ramifications of modern industry has become part of the established corpus of the law of the commerce clause:

"To regulate the price for such transactions is to regulate commerce itself, and not alone its antecedent conditions or its ultimate consequences. The very act of sale is limited and governed. Prices in interstate transactions may not be regulated by the states. . . . They must therefore be subject to the power of the nation unless they are to be withdrawn altogether from governmental supervision. ...

"Regulation of prices being an exercise of the commerce power . . .

58 Helvering v. Davis, 3or U. S. 619, 640-4r, 644-45 (1937).

59 United States v. Butler, 297 U. S. I (1936).

oo NLRB v. Jones \& Laughlin Steel Corp., 3or U. S. I (1937); NLRB v. Fruehauf Trailer Co., id. at 49 ; NLRB v. Friedman-Harry Marks Clothing Co., id. at 58; Associated Press v. NLRB, id. at 103 ; and Washington, Va. \& Md. Coach Co. v. NLRB, id. at 142 . 
the question remains whether it comes within that power as applied to intrastate sales where interstate prices are directly or intimately affected. ... Sometimes it is said that the relation must be 'direct' to bring that power into play. . . . At times, . . . the waves of causation will have radiated so far that their undulatory motion, if discernable at all, will be too faint or obscure, too broken by cross-currents, to be heeded by the law. In such circumstances the holding is not directed at prices or wages considered in the abstract, but at prices or wages in particular conditions. . . . Always the setting of the facts is to be viewed if one would know the closeness of the tie. . . . The power is as broad as the need that evokes it." 01

If he seemed to throw his weight to the side of national power it was not because of any strong doctrinaire beliefs or political preferences. Thus he decided against New York in one aspect of its milk control legislation, doubtless with special sympathy for the difficulties which confronted the state, because he could not escape the conviction that New York was in effect erecting a barrier where the commerce clause enjoined free trade:

"What is ultimate is the principle that one state in its dealings with another may not place itself in a position of economic isolation. Formulas and catchwords are subordinate to this overmastering requirement. Neither the power to tax nor the police power may be used by the state of destination with the aim and effect of establishing an economic barrier against competition with the products of another state or the labor of its residents. Restrictions so contrived are an unreasonable clog upon the mobility of commerce. They set up what is equivalent to a rampart of customs duties designed to neutralize advantages belonging to the place of origin. . . . The form of the packages in such circumstances is immaterial, whether they are original or broken. The importer must be free from imposts framed for the very purpose of suppressing competition from without and leading inescapably to the suppression so intended." 62

These were not matters that closely touched his private intellectual interests. He decided as he decided and wrote what he

61 Carter v. Carter Coal Co., 298 U. S. 238, 324, 326-28 (1936) (dissenting). Cf. Mrr. Justice Cardozo's concurring opinion in Schechter Poultry Corp. v. United States, 295 U. S. $495,55 \mathrm{I}, 554$ (1935), where similar views were expresed less explicitly.

62 Baldwin v. Seelig, 294 U. S. 5II, 527 (r935) (holding unconstitutional, as a

II7 COL.

YALE 487

HARV. 469 
wrote because the judicial function as he conceived it and so candidly set it forth in his philosophic writings compelled his votes and indicated the direction of his opinions.

To adapt a favorite quotation of his, these extracts are but little fragments of the golden fleece that Cardozo has left upon the hedges of his judicial life. But even the fullest reading of his opinions merely gives intimations of his depth of thought and beauty of character. The permanent influence of this great judge was achieved only partially by his own writings, for the current of his culture permeated in ways more subtle than even his opinions can express. Perhaps his qualities are best defined by saying that Cardozo completely satisfied the requirements of a judge wholly adequate for the Supreme Bench.

"I venture to believe that it is as important to a judge called upon to pass on a question of constitutional law, to have at least a bowing acquaintance with Acton and Maitland, with Thucydides, Gibbon and Carlyle, with Homer, Dante, Shakespeare and Milton, with Machiavelli, Montaigne and Rabelais, with Plato, Bacon, Hume and Kant, as with the books which have been specifically written on the subject. For in such matters everything turns upon the spirit in which he approaches the questions before him. The words he must construe are empty vessels into which he can pour nearly anything he will. Men do not gather figs of thistles, nor supple institutions from judges whose outlook is limited by parish or class. They must be aware that there are before them more than verbal problems; more than final solutions cast in generalizations of universal applicability. They must be aware of the changing social tensions in every society which make it an organism; which demand new schemata of adaptation; which will disrupt it, if rigidly confined." ${ }^{33}$

HaRvard Law Schoor.

Felix Frankfurter.

burden on interstate commerce, that portion of the New York Milk Control Act prohibiting the sale of milk imported from another state if the price paid to the producer in the other state was less than the minimum price prescribed by New York for purchases from New York producers). Cf. Mr. Justice Cardozo's opinion in Henneford v. Silas Mason Co., 300 U. S. 577 (1937), upholding the Washington compensating use tax.

${ }^{63}$ L. Hand, Soutces of Tolerance (I930) 79 U. oF PA. L. REv. I, I2.

470 HARV.

488 YALE

COL. II8 